\title{
Article \\ What Makes Agroforestry a Potential Restoration Measure in a Degraded Conservation Forest?
}

\author{
Murniati $^{1, *}$, Sri Suharti ${ }^{1}$, Minarningsih ${ }^{1}{ }^{1}$, Hani Sitti Nuroniah ${ }^{1}$, Subekti Rahayu ${ }^{2}$ and Sonya Dewi ${ }^{2}$ \\ 1 Forest Research and Development Centre, Ministry of Environment and Forestry, Bogor 16610, Indonesia; \\ suharti23@gmail.com (S.S.); minarningsih1975@gmail.com (M.); hsnuroniah@gmail.com (H.S.N.) \\ 2 World Agroforestry (ICRAF) Indonesia, Bogor 16115, Indonesia; s.rahayu@cgiar.org (S.R.); \\ s.dewi@cgiar.org (S.D.) \\ * Correspondence: murni3008@yahoo.com; Tel.: +62-815-8602-2773
}

Citation: Murniati; Suharti, S.; Minarningsih; Nuroniah, H.S.; Rahayu, S.; Dewi, S. What Makes Agroforestry a Potential Restoration Measure in a Degraded Conservation Forest? Forests 2022, 13, 267. https:// doi.org/10.3390/f13020267

Academic Editors: Rebecca Jordan and Amanda Sorensen

Received: 15 December 2021

Accepted: 31 January 2022

Published: 8 February 2022

Publisher's Note: MDPI stays neutral with regard to jurisdictional claims in published maps and institutional affiliations.

Copyright: (C) 2022 by the authors. Licensee MDPI, Basel, Switzerland. This article is an open access article distributed under the terms and conditions of the Creative Commons Attribution (CC BY) license (https:// creativecommons.org/licenses/by/ $4.0 /)$.

\begin{abstract}
Agroforestry is a win-win solution in terms of restoring forest function while benefiting the local community. This research aimed to (1) understand the regulations concerning conservation forest management and the restoration strategies adopted based on the history of forest degradation in the area, (2) investigate the factors driving local people to adopt agroforestry systems in the area, and (3) investigate the characteristics of the agroforestry system developed and its impacts based on farmers' perceptions. This research was performed in Wan Abdul Rachman Grand Forest Park, Lampung Province, Indonesia, and involved 59 respondents who managed 63 agroforestry plots in the area. Several schemes had been implemented to restore the degraded forest without involving the community, and the results were unsatisfactory. Changing the regulations concerning managing conservation forests to involve the community and providing legal permits and support from the management improved forest function due to community willingness to implement the agroforestry system. About $81 \%$ of observed plots consisted of 5-12 plant species, and $16 \%$ of plots consisted of 13-16 species per plot. Theobroma cacao was the most common species in the agroforestry plots, followed by Durio zibethinus, Parkia speciosa, and Aleurites moluccana. The size of the agroforestry plot affected the number of species in the plot. The community perception demonstrated that agroforestry has positive impacts on livelihood, the environment, and biodiversity at the landscape level.
\end{abstract}

Keywords: restoration strategy; driving factors; community's livelihood; species occurrence; principal component analysis; plot size; environment; biodiversity

\section{Introduction}

Protected areas provide ecosystem benefits, such as enhanced carbon stock, clean air and water, healthy soil, nutrient cycles, and wild food and animals, which support societies under increasing stress from human pressures and climate change. Wild creatures such as pollinators, predators, and seed dispersers that use a protected area as their habitat strengthen agricultural resilience. Maintaining biodiversity in a protected area, particularly wild animals in relation to crops, is essential for productive and ecologically sustainable agriculture [1]. Although several factors threaten their effective management, protected areas serve as an effective tool for biodiversity conservation [2].

Forest conversion to monoculture cash cropping, the use of fertilizers and pesticides, and high-yielding varieties in order to maximize production influence the diversity of flora and fauna [3]. Currently, the existing protected areas are not sufficient to overcome the biodiversity crisis $[4,5]$. The international community is continuing to work to improve protected areas that can significantly increase biodiversity. In Indonesia, there are two categories of protected areas for biodiversity and environmental service conservation purposes, i.e., protected forests and conservation forests. In terms of the level of protection, conservation forests have a higher level of protection than protected forests. A grand forest 
park (GFP) is a conservation forest that is managed at the provincial level; it functions as a life support system and preserves the diversity of flora and fauna and the uniqueness of natural phenomena. Wan Abdul Rachman Grand Forest Park (WAR GFP) is a conservation forest of 22,245.50 ha that is located in Pesawaran District, Lampung Province, Sumatera, Indonesia [6]. The forest cover in WAR GFP declined significantly in the 1994-2000 period (from 9090.11 ha in 1994, to 6288.71 ha in 1997, and 5428.74 ha in 2000) [7]. There were 39 villages located adjacent to WAR GFP. Cutting and clearing the forest in WAR GFP to cultivate crops was started by transmigrants from Java when the area was managed as Gunung Betung Protection Forest (GBPF) [8]. Since the 1950s, people have lived in and around the GFP and taken advantage of the forest land to grow annual crops for economic gain $[9,10]$. Conversion of forest to agricultural land has a negative impact on the ecosystem, including changing the biological, physical, and chemical properties of the soil [11]. This increases pressure on the forest cover. In addition, forest fires and illegal logging have occurred frequently [12].

Various attempts have been made to restore the vegetation cover in WAR GFP through a long up-and-down process. National programs by the Forest and Land Rehabilitation Movement (Gerakan Nasional Rehabilitasi Hutan dan Lahan, GERHAN), Community-Based Forest Management (Pengelolaan Hutan Bersama Masyarakat, PHBM), and Community Forestry (Hutan Kemasyarakatan, HKm) were implemented in the area to restore forest cover. Forest cover increased slightly but has not been able to keep up with the rate of forest encroachment activities of the community. Then, around 2012, collaborative management was implemented involving the community and the forest cover began to increase significantly $[7,12]$.

Forest cover in WAR GFP increased to 8952.98 ha in 2014 as there was a change from monoculture annual crops to mixed gardens or complex agroforestry systems like forests [7]. Agroforestry is a land management technique that integrates forest trees with agricultural crops. This technique optimizes production and income per unit area, and its main principles are sustainable, multi-use, and optimal land management, and adoption by local cultures [13-15]. Another management policy developed by the government awards a temporary community forest concession permit (for a 5-year period) to the community surrounding WAR GFP. The program was launched in 1999 following the issuance of Minister of Forestry Decree No. 677/Kpts-II/1998 (MoF) concerning Community Forestry $(\mathrm{HKm})$, and one Joint Forest Management and Conservation Group was allowed to manage an area of 492.75 ha [12].

Many studies have shown that the main driving factors that influence a community's willingness to develop agroforestry are the economic, social, financial, and biophysical factors of the land and poverty reduction [16-19]. However, the willingness to implement agroforestry is a more complex process because it involves a series of decisions that include the selection of the optimal combination of commodities, which requires the careful calculation of input use and time [20]. There remain gaps in our understanding concerning the adoption process and the intensity of community agroforestry adoption [21]. Although many previous studies have considered agroforestry adoption as a binary option [22-25], there are other factors at play, namely social capital and network variables, which also have an important influence on whether or not potential adopter farmers adopt agroforestry as a sustainable farming technique [21]. Agroforestry, which was widely developed by local people in WAR GFP, contributed to improving the ecological function [9], with similar cases being reported in Nepal [26] and other countries [14].

Increasing forest cover in WAR GFP during 2000-2014 is an interesting case in terms of restoring the forest function and environment services. The aims of this study were to (1) understand the regulations concerning conservation forest management and the restoration strategies adopted based on the history of forest degradation in the area, (2) investigate the factors driving local people to adopt agroforestry systems in the area, and (3) investigate the characteristics of the agroforestry system developed and its impacts based on farmers' perceptions. 


\section{Materials and Methods}

\subsection{Study Area Description}

The research was conducted in Wan Abdul Rachman Grand Forest Park (WAR GFP), Pesawaran District, Lampung Province, Indonesia, which is between $05^{\circ} 23^{\prime} 47^{\prime \prime}$ to $05^{\circ} 30^{\prime} 35^{\prime \prime} \mathrm{S}$ and $105^{\circ} 02^{\prime} 42^{\prime \prime}$ to $105^{\circ} 13^{\prime} 42^{\prime \prime}$ E [6] (Figure 1). The research was performed from March to November 2018.

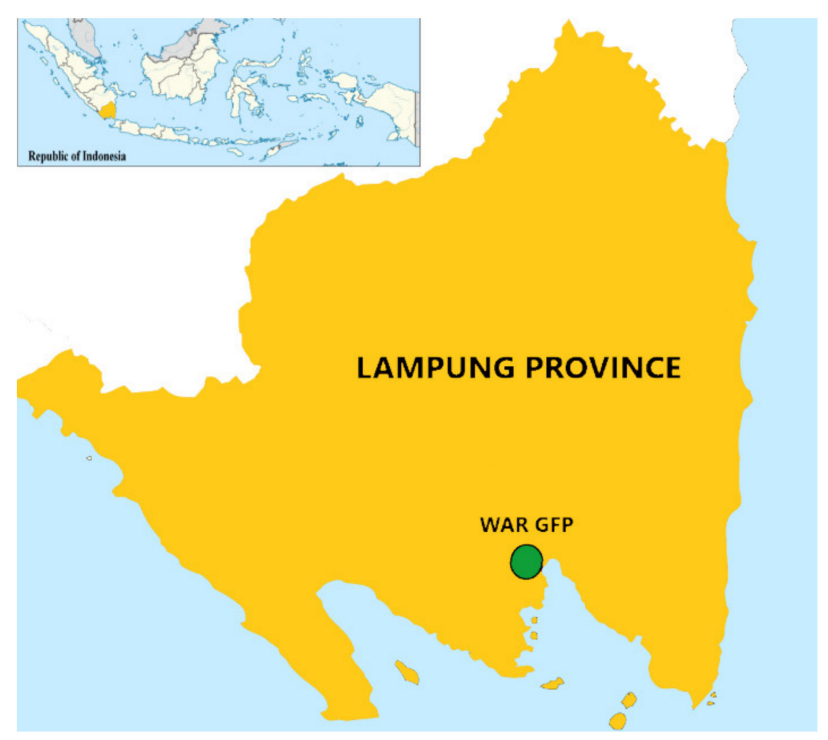

Figure 1. Research location at Wan Abdul Rachman Grand Forest Park (WAR GFP), Pesawaran District, Lampung Province, Sumatra, Indonesia.

WAR GFP was established in 1993. Previously, this area was designated as Gunung Betung Protection Forest (GBPF). Forest degradation in this area began a long time before WAR GFP was established. The transmigration program from Java began affecting the area in the 1950s, which was the starting point of the forest degradation process. In 1965, the community gradually began to enter the forest to cultivate annual food crops, such as rice, maize, and banana. After two or three seasons of annual food crop cultivation, there was a shift to longer-lived perennial crops such as coffee, cocoa, and clove. The main factors driving the community to cultivate in the conservation forest are related to economics. This was confirmed in previous studies that found that landlessness and the need to develop a greater variety of species encouraged land encroachment $[8,27,28]$.

Changing plant species from annual to perennial crops led to more intensive management and increased income. Thereafter, the community started to build a settlement in the conservation forest area. Various social facilities, such as schools and markets, were built inside the conservation forest area, which eventually encouraged them to build a village. The situation continued until 1993 when the GBPF was designated as WAR GFP.

After this, the management of the area fell under the control of the WAR GFP manager without the involvement of the communities who had a close interaction with the forest area. There was a lot of social conflict with the local community who had strong dependencies on the surrounding forest.

\subsection{Data Collection}

Farmer interviews were carried out using a structured questionnaire to obtain information concerning driving factors of forest degradation in WAR GFP, factors driving communities to develop the agroforestry system, variables of the agroforestry system (size of cultivated areas, distance from settlement to farming plot, on-farm and off-farm activities, list of species cultivated), and the impact of agroforestry practices on the environment, biodiversity, and farmers' socio-economic status. Fifty-nine respondents who worked 
on sixty-three plots were selected purposively from two villages, namely Bogorejo and Cilimus, based on the following criteria: (a) individuals who practice agroforestry in the area and (b) members of the forest farmer groups. Purposive sampling is a nonrandom sampling technique whereby the researcher determines the sample while considering specific characteristics that are in accordance with the research objectives [29].

The impact of agroforestry practice on the environment, biodiversity, and community socio-economic status was assessed using a before-and-after analysis. Each respondent was asked to describe the level of impact of each indicator. The existing condition (about 20 years after establishment) was then compared with the condition before agroforestry was established in 1998-2000. There were four options for describing the condition of each indicator: decrease, no change, increase, and no answer. There were various indicators to assess agroforestry impacts, i.e., (a) impact on the environment (water limpidity during the dry season for water quality, river water surface level for water quantity, and turbidity level in the rivers soon after heavy rain for soil erosion); (b) impact on biodiversity variables (trend of flora and fauna species richness, tree density, and tree cover per unit area); and (c) impact on social and economic variables (food crop production, nonfood crop production, cash income, saving, landholding, food availability assurance, luxury goods possession, access to information and skill, easy access to financial assistance/loans, institutional strengthening, representation in decision making, law enforcement). A key informant interview was conducted with WAR GFP officers to obtain information on the management of WAR GFP, the history of forest restoration in the area, and the process of involving the local community in forest restoration activities.

\subsection{Data Analysis}

Principal component analysis (PCA) [30] was used to analyze the correlation between the group of respondents who practiced agroforestry in the area and the variables that potentially influenced factors, such as plot size managed by each farmer, distance from farmer's settlement to the agroforestry plot, farmer activities (on-farm and off-farm), and amount of harvested and non-harvested plants. The following four groups based on the number of species cultivated in the plot were used in the analysis: (A) 1-4 species cultivated, (B) 5-8 species cultivated, (C) 9-12 species cultivated, and (D) 13-16 species cultivated. The grouping number of species cultivated in the plot was determined based on the total number of species cultivated by all 59 respondents. Frequency, relative to all respondents, was used based on the condition trend of the environment, biodiversity, and socio-economic indicators to measure the impact of agroforestry systems.

\section{Results}

\subsection{Restoration Efforts and Challenges to Their Implementation}

Several programs aiming to restore the forest had been developed in the past. A reforestation program was executed in 1982, which involved planting various forest tree species, such as Dalbergia latifolia, Litsea spp., and Pterospermum spp. Although some of those trees grew, because of a lack of plant maintenance, their survival rate was less than $10 \%$. During reforestation, the government blocked areas for settlements, markets, and schools and the people were transmigrated to the Mesuji area. Soon after, the people returned to their previous settlement as they could not afford to engage in wet rice farming in the transmigration area. Unfortunately, the increase in population had caused a decrease in landholding, which rendered farming unfeasible. These then pushed the community back into the forest for the cacao, coffee, and clove plants that were ready to be harvested. Hence, economic factors drove the community to develop farming in the conservation forest. In our study, $88 \%$ of respondents reported poverty to be the main reason for this, followed by utilizing unmanaged land (12\%).

Restoration programs were carried out in 1998, including the Forest and Land Rehabilitation Movement (Gerhan), Community-Based Forest Management (PHBM), and the provision of seedlings of forest trees and multipurpose tree species (MPTS) to smallholder 
farmers. The growth of tree species developed in Gerhan Programs, such as petai (Parkia speciosa), durian (Durio zibethinus), and candlenut (Aleurites moluccana), was relatively good. Training and technical assistance was also provided to induce the planting of high-crowned species with deep-rooted plants such as candlenut, durian, and petai.

3.2. Regulations Regarding the Management of the Conservation Area with the Involvement of the Local Community

As previously stated, the involvement of the local community began in 1998 with the issuance of Ministerial Regulation No. 677 on the Community Forestry, although the program only ran temporarily. In 2012, through Provincial Regulation Number 3, a collaborative management scheme aiming to accommodate community needs and prevent future damage was developed inside the WAR GFP. With this strategy, land cover in WAR GFP increased significantly. An agroforestry cropping pattern was developed, with a combination of rubber, cocoa, MPTS, and forest tree species. Communities were able to take advantage of nontimber forest products (NTFPs) to ensure their welfare, and woody plants were planted to preserve the forest. In 2018, collaborative management with the local community was strengthened by the issuance of the Conservation Partnership Program through Director General KSDAE (Natural Resources and Ecosystem Conservation) Decree No 6/KSDAE/SET/Kum.1/6/2018. The Conservation Partnership is also one of the schemes developed under the Social Forestry Program as a policy umbrella for community involvement in forest management (Figure 2).

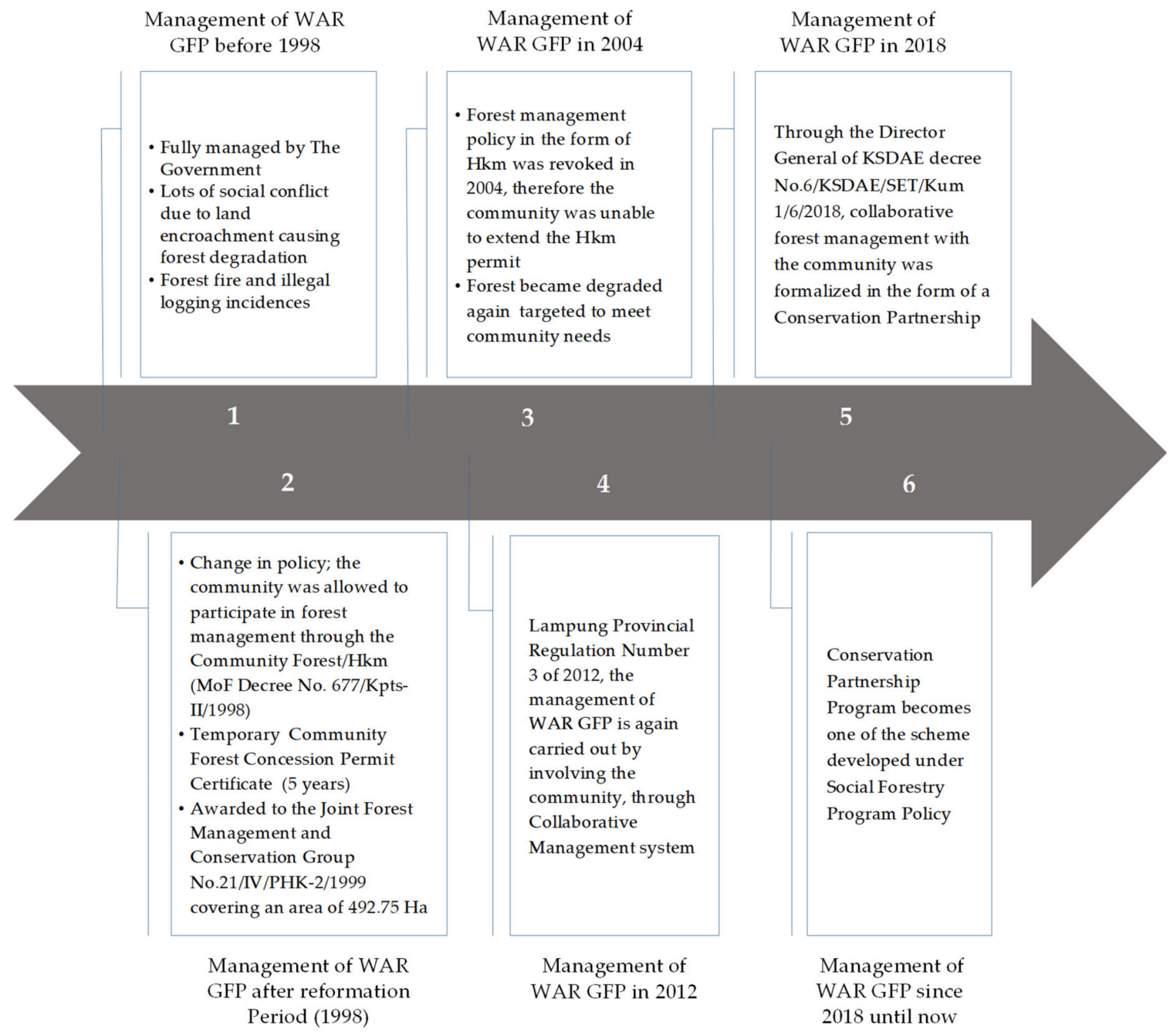

Figure 2. Management dynamics of Wan Abdul Rachman Grand Forest Park (WAR GFP). 


\subsection{Driving Factors of Communities in Developing the Agroforestry System in WAR GFP}

Factors driving the community to develop the agroforestry system in the WAR GFP can be classified into three aspects: social-economic-cultural, ecology, and stakeholder initiative aspects. For the social-economic-cultural aspects, livelihood was the most important driving factor for $78 \%$ of the respondents (Figure 3a). As regards the ecological aspect, the most essential driving factors were reduced land productivity, water shortages, and high soil erosion, which were reported by about $19 \%$ to $22 \%$ of respondents (Figure $3 b$ ). For the stakeholder initiative aspect, community initiative was the most important driving factor (as stated by $51 \%$ of respondents), followed by the government initiative (as stated by $28 \%$ of respondents (Figure 3c)).

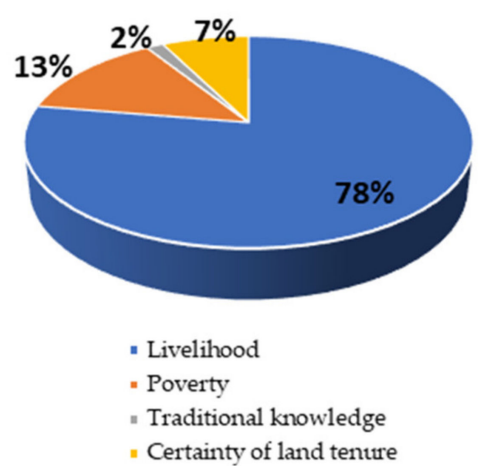

(a)

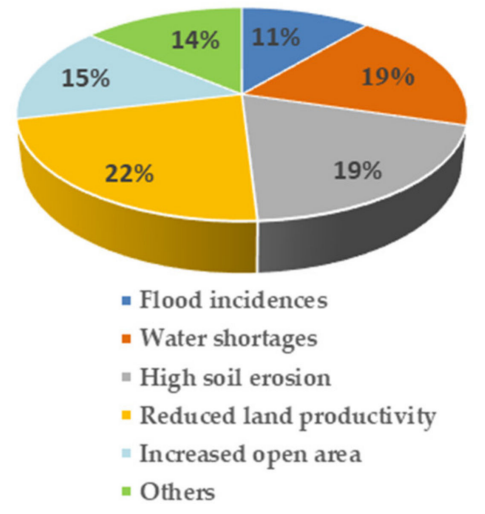

(b)

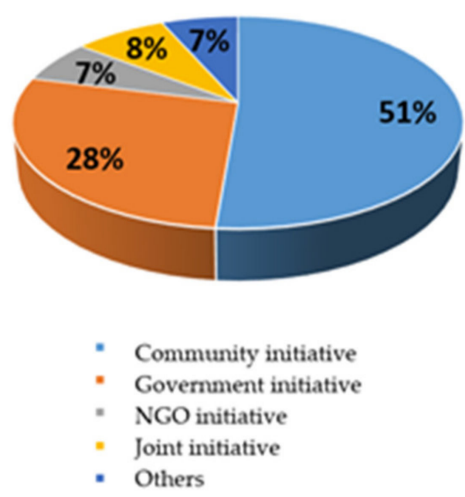

(c)

Figure 3. Factors driving communities to develop the agroforestry system in WAR GFP: (a) socialeconomic-cultural aspect, (b) ecological aspect, and (c) stakeholder initiative aspect.

\subsection{Characteristics of the Agroforestry System Developed in WAR GFP}

Farmers who managed land in WAR GFP cultivated 1 to 16 plant species in each plot, with most farmers developing complex systems with five or more species in each plot. From 63 plots, 2 plots consisted of $1-4$ species, 25 plots consisted of $5-8$ species, 26 plots consisted of 9-12 species, and 10 plots consisted of 13-16 species. The total number of species cultivated in 63 plots was 55 (Appendix A), which were classified into three groups: (1) 27 species of MPTS, (2) 18 species of forest trees, and (3) 10 understory species. Most of the farmers combined those three groups of species in their plot.

Cacao (Theobroma cacao), durian (Durio zibethinus), petai (Parkia speciosa), and candlenut (Aleurites mollucana) were the most common species cultivated by farmers in WAR GFP. These tree species were found in 78-93\% of the 63 managed plots. The second most frequent group of species was nutmeg (Myristica fragrans), clove (Syzygium aromaticum), jering (Archidendron pauciflorum), melinjo (Gnetum gnemon), and rubber (Hevea brasiliensis), which were found in $48-59 \%$ of the plots (Figure 4).

Forest species including binong tabu (Tetrameles nudiflora), cempaka (Michelia champaca), and pulai (Alstonia scholaris) were found in less than $22 \%$ of plots. Moreover, Dalbergia latifolia, Litsea spp., and Pterospermum spp., which are forest species that were planted for forest rehabilitation purposes in 1982, were reported in less than $10 \%$ of plots.

The assessment of factors (PCA) shows that there were two-way positive correlations between variables (Figure 5 and Table A2), i.e., a correlation between plot size and two other variables (number of harvested species, number of non-harvested species). The PCA result also indicates that a larger distance between farmer plots and the settlement/village and having an off-farm job encouraged the farmers to apply a simpler agroforestry pattern with a smaller number of planted species $(\leq 8)$. Farmers with a larger amount of cultivated land tended to apply more complex agroforestry with a greater number of plant species. 


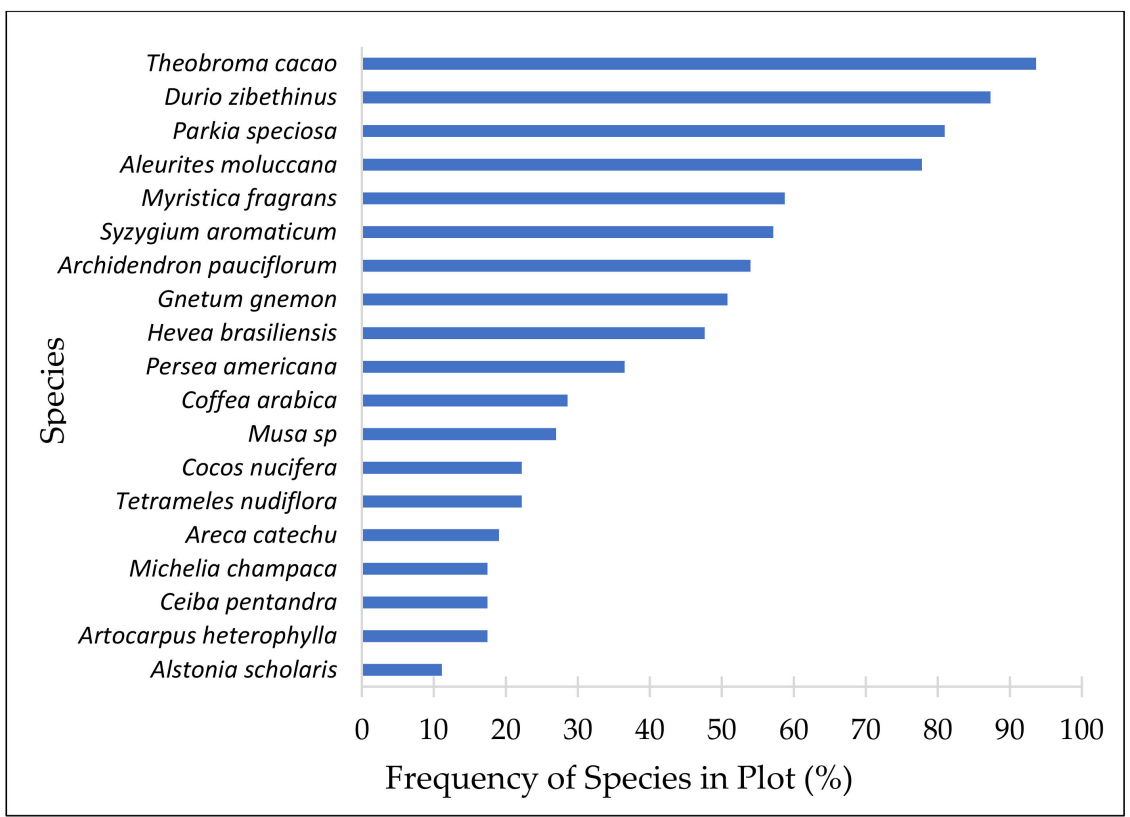

Figure 4. Frequency of species in the 63 managed plots (\%) in WAR GFP.

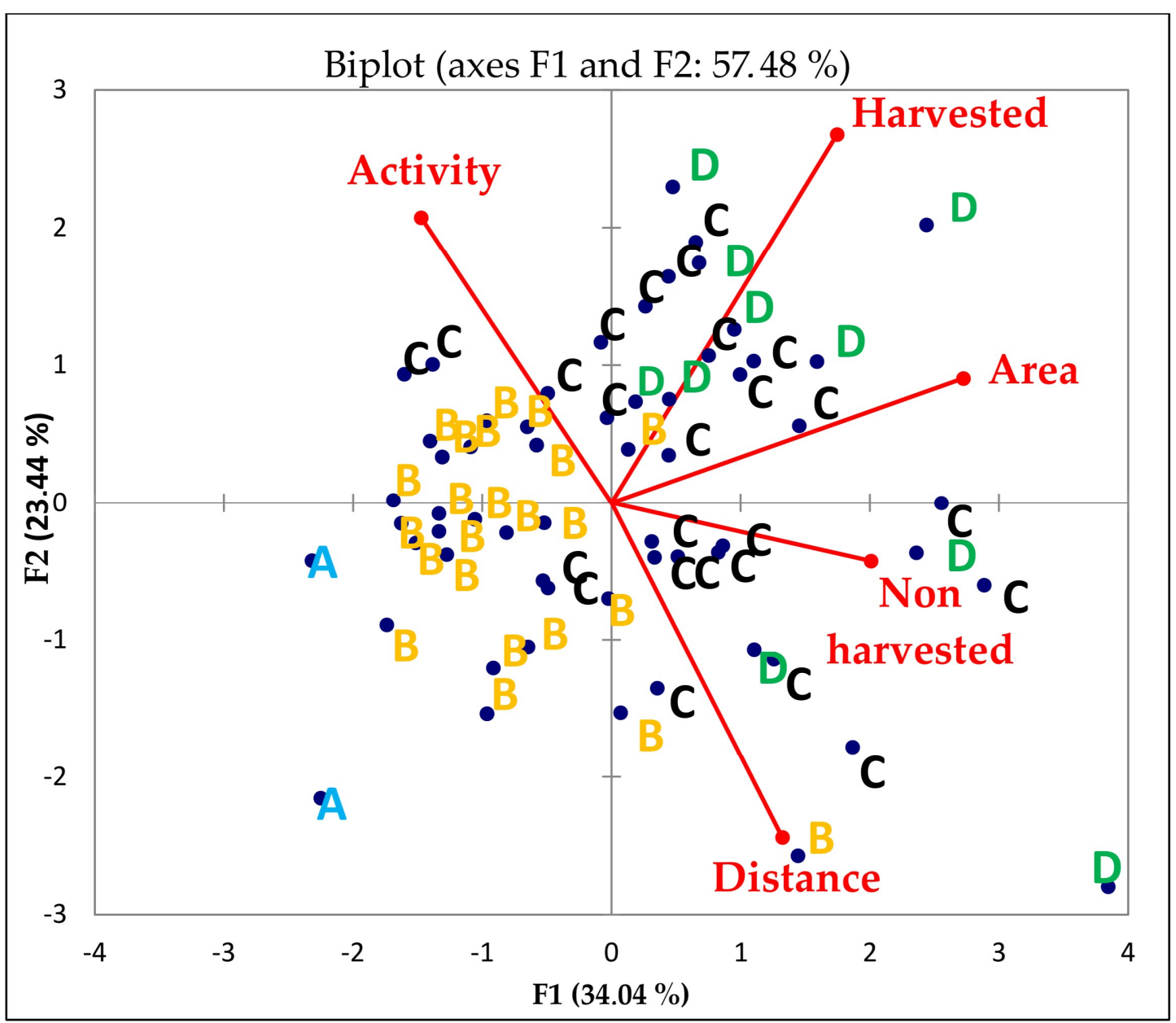

Figure 5. Correlation between several variables and the number of species cultivated in each plot. (A) 1-4 species cultivated, (B) 5-8 species cultivated, (C) 9-12 species cultivated, and (D) 13-16 species cultivated. 


\subsection{Agroforestry Impact on the Environment, Biodiversity, and Socio-Economic Status}

As compared to the last two decades, considering that agroforestry had just been established by the community in 2000 , more than $50 \%$ of the respondents mentioned that the environment indicators had improved (Figure 6). The availability of clean water increased, the level of soil erosion decreased, water quality and quantity increased, while landslide frequency remained the same. Most of the respondents $(>88 \%)$ noticed that the agroforestry that they practiced in the plot had significantly increased the tree population, tree cover, and the diversity of flora over the two decades (Figure 7).

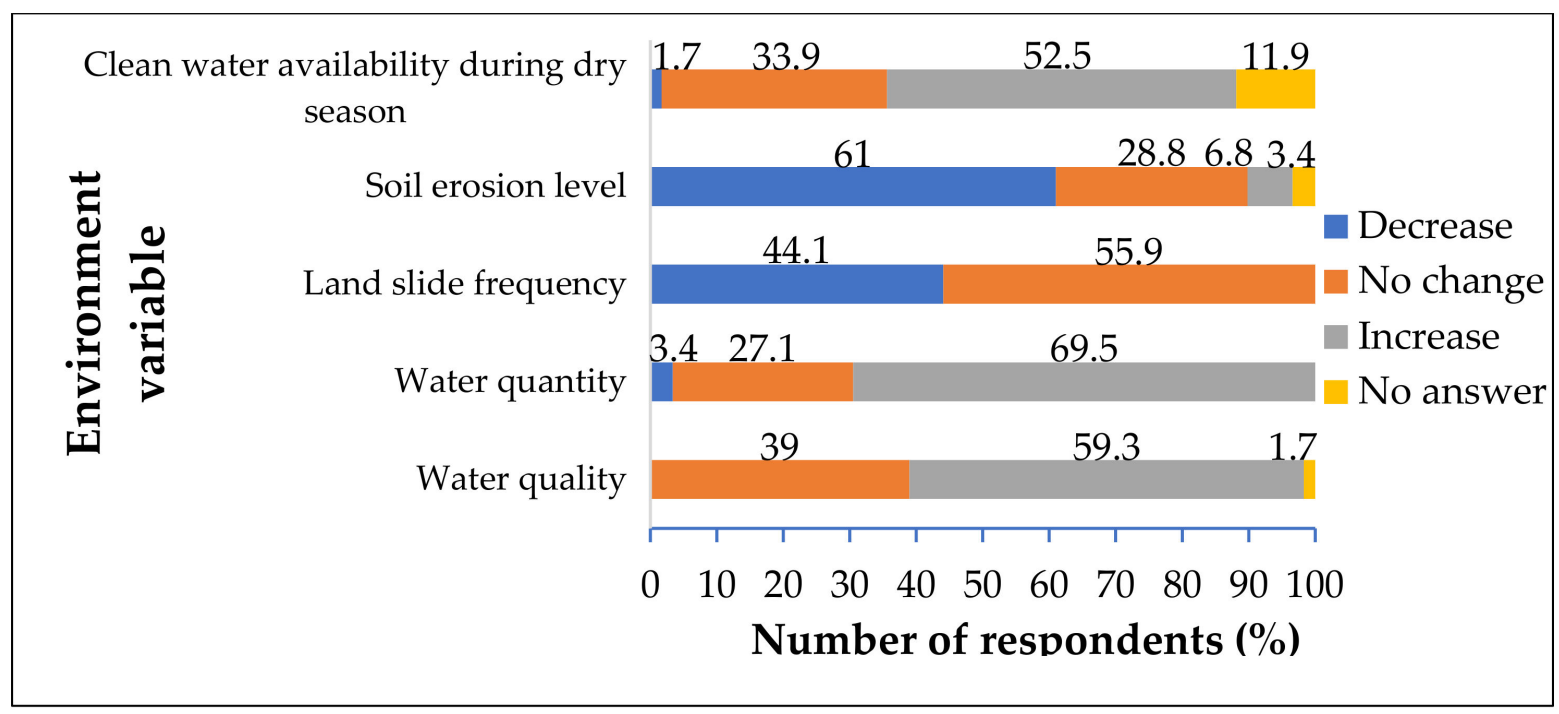

Figure 6. Impact of agroforestry practice on certain environment variables in WAR GFP.

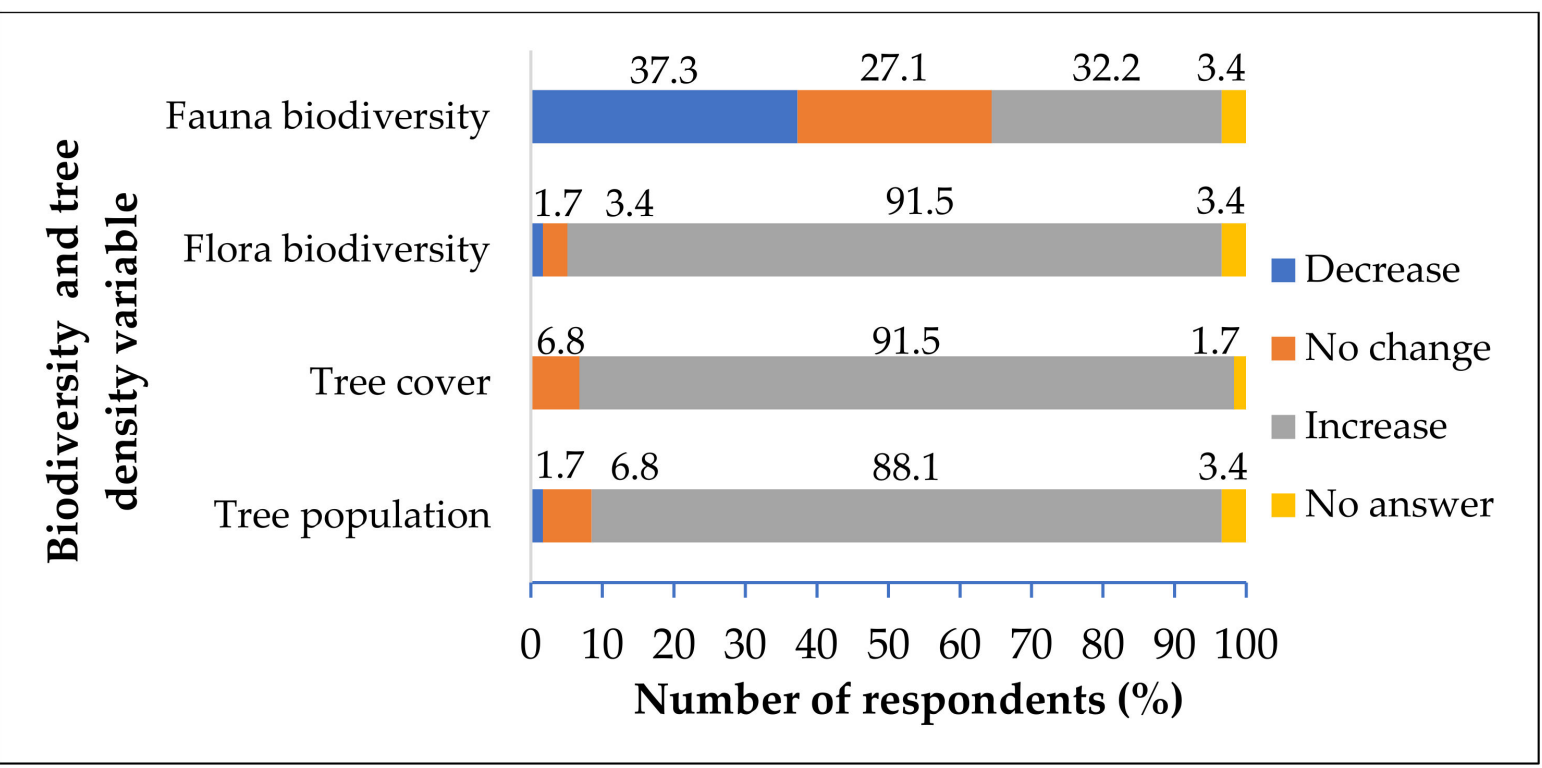

Figure 7. Impact of agroforestry development on certain biodiversity and tree density variables in WAR GFP.

More than $80 \%$ of respondents reported that food crop production, cash income, food availability, luxury goods possession, access to information and skill, easy access to financial loans, institutional strengthening, representation in decision making, and law enforcement had improved (Figure 8). However, agroforestry was considered to have no impact on savings and the size of land ownership. 


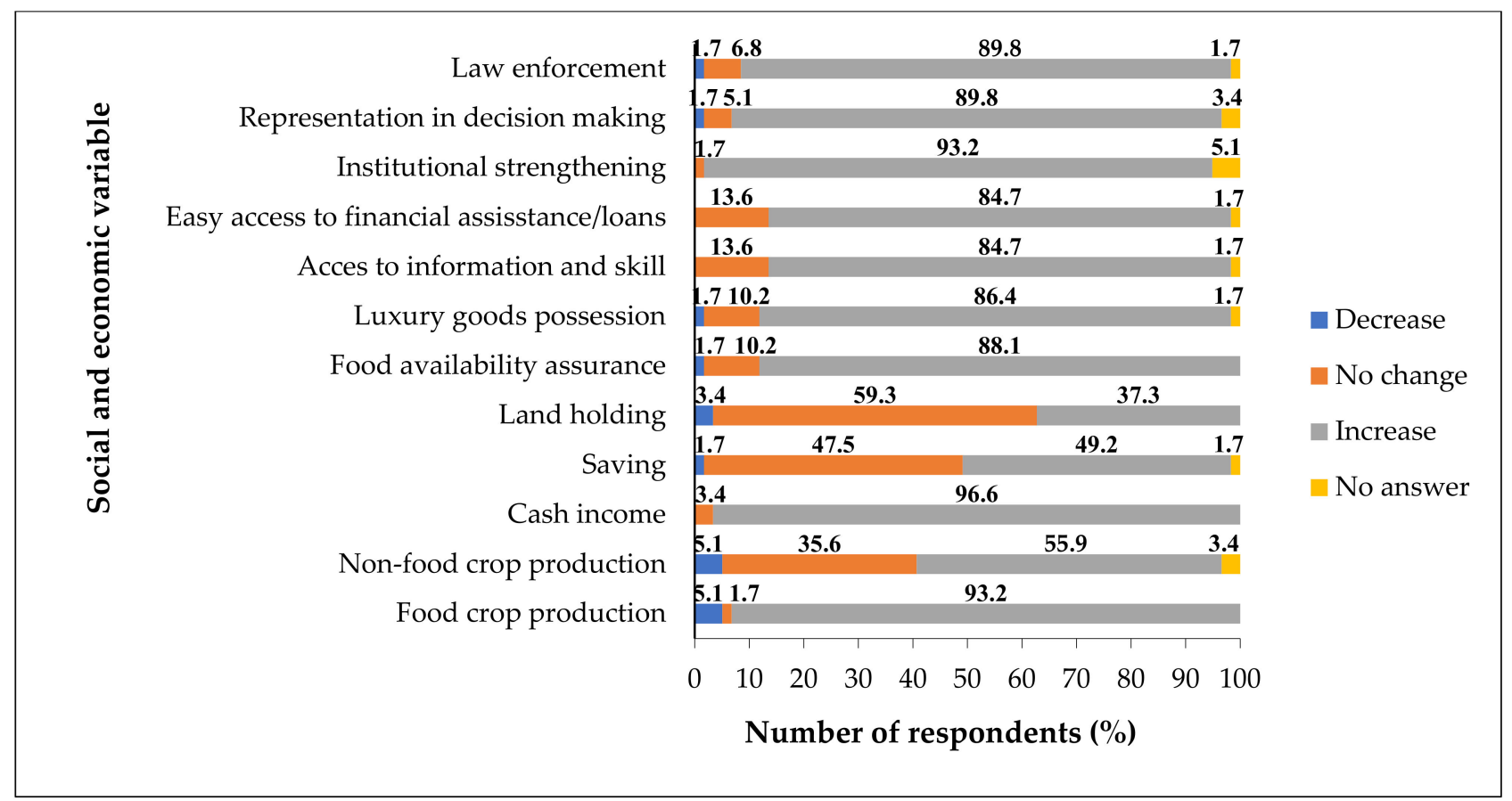

Figure 8. Impact of agroforestry development on socio-economic status of the community in WAR GFP.

\section{Discussion}

\subsection{Restoration Efforts and Challenges to Their Implementation}

Several programs were initiated by the government to restore the degraded forest due to community encroachment; unfortunately, the majority were unsuccessful. The community forestry program $(\mathrm{HKm})$, which was considered the most promising policy, was not able to significantly improve the degraded forest in WAR GFP as it only ran temporarily. It was expected that community access to forest management through the $\mathrm{HKm}$ would last longer in terms of accommodating the economic needs of the community and fostering forest sustainability. Unfortunately, in 2004, the Community Forestry policy was canceled and people lost their legal access to cultivate in WAR GFP [12]. The lack of legal access to WAR GFP encouraged people to invade the forest for farming activities as was the case before. Although the scale of forest encroachment was not as severe as before 1999, the decline in forest cover continued until 2012 [7].

There were some areas in WAR GFP that had been damaged by logging and fire and were overgrown with weed (Imperata cylindrica). People replanted the areas with various plant species, did not cut or clear land, and instead replanted on vacant land. This is interesting because, despite encroaching on the forest, they entered WAR GFP for planting on vacant land with various plant species. Although the main goal may have been to obtain economic benefits from the planted crops, replanting on vacant land can be considered a positive impact of forest encroachment. This increased awareness of WAR GFP management in terms of the importance of accommodating the interests of the community who already existed in WAR GFP. Subsequently, the government realized that WAR GFP management would not succeed without local community involvement. This became the momentum for policy changes in forest management. Thereafter, different approaches were utilized that involved the community in WAR GFP management.

4.2. Regulations Regarding the Management of the Conservation Area with the Involvement of the Local Community

Although several programs were developed by the government to involve the local community in the WAR GFP management, until the mid-1990s, forest management in In- 
donesia was dominated by a command-and-control approach. At that time, the community was not considered an equal partner; hence, the level of community involvement was low and several repressive efforts to remove them from the forest led to social conflict.

Learning from the situation, community involvement in WAR GFP management has become an alternative solution. With this, land cover in WAR GFP has increased significantly. The strategy to encourage farmers to plant tree crops with multi-story canopies and a deep-rooted system that mostly produce foods, while allowing them to maintain their cacao, coffee, and clove in WAR GFP, was a win-win solution for situations in which forest encroachment had occurred. The management policy dynamics in WAR GFP that caused the forest destruction to be repeated proved that successful management must provide space for the surrounding community to benefit from the forest and participate in forest management [28,31].

Subsequently, offering legal access to cultivating forest land inside WAR GFP became the main factor encouraging the community to apply agroforestry. Securing access to forests induces farmers to invest in the long term, which benefits them in the long term [32]. With this approach, both community access and the income from the forest land is sustainable. Establishing a win-win approach is the best strategy to build an agroforestry system in the conservation area. However, commitment to safeguarding the interest and role of the WAR GFP manager and the community is required to ensure the sustainable management of WAR GFP. The proper use of forests, forest products, and sustainable management significantly contributes to income and employment generation and reducing poverty, and it provides a vital role for biodiversity conservation, environmental protection, and ecological balance.

\subsection{Driving Factors and Characteristics of the Agroforestry System Developed in WAR GFP}

Livelihood was the most important driving factor from the social-economic-cultural aspects in developing agroforestry in WAR GFP. By practicing agroforestry, farmers have the chance to work and obtain yields from various plant species around the year and income for their families. A study in Northern Bangladesh found that practicing agroforestry increased farmer livelihood enormously as they had more access to food, fodder, and fuelwood. Furthermore, agroforestry practices increased plant species diversity, ensured economic return, and sustained farmers' livelihoods [33].

Community initiative is very important in initiating and conducting a program because it affects its sustainability. The community initiative in agroforestry development was supported by the government, who managed the conservation forest park by providing the community with tree crop seedlings, empowering the farmers through crop cultivation training, and strengthening farmer institutions. These factors all led to the success of agroforestry development in WAR GFP. This is in accordance with the success of Community-Based Natural Resource Management in Kenya and Australia, which were initiated by the communities themselves, rather than by donors, state managers, or researchers [34].

The high occurrence of species in managed plots indicated the farmers' preference for certain species. The most common species produced economic products to generate income. The main reasons for agroforestry adoption were to improve farmers' livelihoods by increasing income (51.7\%), crop yield (33.3\%), and health and nutrition (15.0\%) [35]. Cultivating species that produce economic products is an effort to improve the livelihood of farmers.

Cacao is mainly cultivated by smallholders in the humid tropics [36] as in Indonesia. Cacao can be planted in a multi-cropping system such as an agroforestry system since this crop needs shading. Hence, as shade trees, farmers plant multipurpose tree species with a high canopy and deep roots, such as durian, petai, and candlenut. Those MPTS planted during the Gerhan program, where the government provided farmers with seedlings, were preferred by farmers because the plants supplied significant food and income. Highcanopy trees enable the crops underneath to capture optimal sunlight, while deep-root 
plants can act as a safety net in nutrient uptake [37-39]. The shade trees should have a role in biodiversity conservation as strategies to encourage ecosystem maintenance and the sustainable management of cacao farmlands [36,40,41]. The abundance of high-canopy and deep-root plant species at the research site played an important role in restoring the degraded conservation forest. Legal access holder to land and economic reasons were the main factors for the community to implement agroforestry systems.

There was a positive correlation between plot size and the number of harvested species. A larger cultivation area enables farmers to plant more species, thus diversifying the farmed products to anticipate crop failure. A greater number of species requires a larger planting area. This supports previous findings that stated that farm product diversification in agroforestry aimed to reduce the risk of yield losses due to pests and disease [42], provide income throughout the year, and buffer incomes when prices for certain products are low $[43,44]$. In addition, for farmers, food and income emerge as the most important reasons for selecting plant species; hence, more cultivated land encourages farmers to choose plant species that can be harvested most [45].

A positive correlation between plot size and the number of non-harvested species planted in the research site may be related to the obligation for the farmers to plant forest tree species for conservation purposes, even though they cannot be harvested by the community. Hence, if the farmland is larger, farmers will have more opportunities to plant forest tree species, following the balance in the WAR GFP. Moreover, they have more space to plant species that can be harvested to fulfill their daily needs. This finding reveals the logical consideration of the farmers in WAR GFP as applied to several restrictions. This confirms previous studies that highlight the value of flexible conservation farming approaches that allow farmers to minimize trade-offs and prioritize their households' needs [46]. Distance from agroforestry plots to farmers' settlements/villages and having an off-farm job influenced the farmers' choice in agroforestry pattern. This is reasonable because a relatively large distance requires more effort, i.e., energy, time, and cost for farming activities. Meanwhile, the farmer with off-farm work has most of their time taken up with that. Hence, applying a simple agroforestry pattern with a smaller number of species $(\leq 8)$ is the most suitable option for them. The fact that farmers with more cultivated land tended to apply more complex agroforestry patterns with a greater diversity of plant species is in line with the results of a previous study in WAR GFP, in which farmers with a relatively larger area of cultivated land (more than $3 \mathrm{ha}$ ) exhibited a preference for tree planting, which brought benefits in the future [47]. A study in Nepal also confirmed that a large cultivated land area guaranteed more food security, and so enabled farmers to allocate part of their land for long-term investments, such as agroforestry with more diverse plant species [48]. Another study demonstrated that the size of cultivated land was a factor that affected the number of species planted by the community on their cultivated land in WAR GFP [8].

\subsection{The Impact of Agroforestry and Enabling Conditions for Its Development}

Most respondents recognized that soil erosion decreased after long-term agroforestry. Increasing ground cover, mainly in the form of the tree canopy, reduces soil erosion as rain does not fall directly on the soil surface. Low or minimum soil erosion positively contributes to soil nutrient availability and soil fertility. Water quality and quantity and the availability of clean water during the dry season were also reported to improve. This is in line with a previous study that reported that agroforestry systems are a vital part of a multifunctional working landscape and provide many ecosystem services [49]. Trees improve the infiltration of water and reduce evaporation and run-off [50]. Agroforestry can improve the major measurable soil metrics that define soil health [51].

At the initial phase of forest land cultivation, farmers only planted annual crops. Subsequently, as mentioned earlier, they planted coffee or cacao and clove with regular planting distances. Later, farmers also planted multipurpose tree species (MPTS) in an empty spot without considering spacing. The main considerations in planting trees and/or 
crop species are that the space receives enough sunlight and its suitability in terms of soil properties. Long-term agroforestry development in forest areas allows farmers to enhance plant density and species diversity. The role of traditional agroforestry practices in supporting tree species richness provides evidence of the farms' role as biodiversity reservoirs [52]. Enrichment planting with high economic value species, suitable to the habitat of the agroforestry system, can enhance species distribution and species heterogeneity [53]. The duration of forest land cultivation affects plant species diversity, i.e., the longer the cultivation activity, the greater the possibility to enhance plant species diversity [8]. Agroforestry can play a major role in conserving and enhancing biodiversity on both the farm and landscape level in both tropical and temperate regions of the world [54].

Furthermore, many studies have confirmed that agroforestry functions as a supporting technique to improve ecological conditions, such as soil fertility and water recycling $[55,56]$. Many agroforestry options achieve this through low external input supplies, high recycling rates, and crop-livestock integration [57]. Other studies have demonstrated that agroforestry system development significantly contributes to the socio-economic status of the community and the local environment $[58,59]$.

Legal access permit to manage forest land in WAR GFP is the main reason for the community to develop agroforestry. In addition, the community's positive perception of the impact of agroforestry development as seen from a socio-economic point of view and community empowerment were other reasons for community willingness to develop agroforestry. These are key lessons for agroforestry development to restore degraded forest areas that have been occupied by people. The community will support the development of agroforestry if the benefits can be felt directly. Similarly, a study from India showed that the economic and social benefits of agroforestry were the determining factors for farmers' willingness to adopt agroforestry as a viable alternative to conventional 'modern' farming practices [60]. The most appropriate and optimum tree-crop combination in agroforestry considerably increases the economic benefits as a result of multiple yearly harvests, leading to increased financial resilience and reduced vulnerability to crop failure, which is commonly found in single-cropping or monoculture practices [61].

It was clearly shown that agroforestry practiced in WAR GFP affected the community's livelihood. This confirmed the findings of other studies that demonstrated that farmers' income from agroforestry practices contributed more than that of non-agroforestry farming systems $[53,62,63]$. A study in Bangladesh also verified that farmers who practiced agroforestry were economically better off than those not practicing it [64]. If developed widely and effectively, agroforestry could make a major contribution to the UN's Zero Hunger Challenge, which aims at ending malnutrition and global hunger, and developing sustainable food systems [65].

Agroforestry provides ecosystem functions close to the forest cover. This is the main reason why agroforestry is being promoted as a system to restore degraded forests, including conservation forests. However, there are various requirements for restoration in a conservation forest, such as survivorship and species diversity. From this research, we can identify enabling factors that potentially support successful restoration programs in conservation forests: (1) legal permission for the community to manage land in the conservation forest; (2) commitment from the conservation forest manager to support the community in managing agroforestry by providing seedlings, information, strengthening skills, participation in species selection, and increasing awareness on the impact of forest degradation; (3) commitment of the community to follow the rules regarding planting tree and/or crop species in the conservation forest through understanding the positive impact of agroforestry; and (4) market availability of commodities.

\section{Conclusions}

Commitment is needed to maintain the interests and roles of both the manager and Wan Abdul Rachman Grand Forest Park (WAR GFP) community in order to establish strong collaboration and conflict resolution in the management of the conservation forest. One 
appropriate strategy in forest restoration that can accommodate ecological and economic interests is the development of an agroforestry system with a multistrata canopy. Multipurpose tree species (Theobroma cacao, Durio zibethinus, Parkia speciosa, and Aleurites moluccana) are both common and produce economic products. The species also play an important role in biodiversity conservation and ecosystem maintenance in restoring the degraded conservation forest of WAR GFP. Farmers with a larger area of cultivated land tended to prefer more complex agroforestry patterns with a greater diversity of plant species A larger distance from farmer plots to the settlement/village and having an off-farm job encouraged farmers to apply more simple agroforestry patterns involving a smaller number of species $(\leq 8)$.

Agroforestry has a positive impact on various environmental variables, i.e., water quality, water quantity, soil erosion, and the availability of clean water during the dry season. Tree population, cover, and the diversity of tree species in the agroforestry plots increased significantly. Agroforestry development also improved the socio-economic conditions of the community through improvements in food crop production, cash income, access to information and financial resources, local institutions, and community skill. The community's positive perception of the impact of agroforestry development as seen from the socio-economic conditions and community empowerment was another factor that influenced the community's willingness to develop agroforestry, as was access permission to manage forest land in WAR GFP.

The success of restoration efforts in the degraded WAR GFP through the development of agroforestry can be used as a model to tackle the complexities of managing degraded conservation areas in Indonesia and other tropical countries facing similar challenges. The Forest Management Authority in WAR GFP should enable the surrounding forest communities' involvement in conservation forest management through the development of agroforestry systems that accommodate both ecological considerations and the economic interests of the community.

Author Contributions: Conceptualization, M. (Murniati) and S.S.; methodology, M. (Murniati), S.S. and M. (Minarningsih); data collection, M. (Murniati) and M. (Minarningsih); software, M. (Minarningsih) and H.S.N.; validation, S.S. and H.S.N.; writing-original draft preparation, M. (Murniati), S.S. and H.S.N.; framing, S.R. and S.D.; writing-review and editing, M. (Murniati), S.S., H.S.N. and S.R.; visualization, H.S.N.; supervision, S.R. and S.D. All authors have read and agreed to the published version of the manuscript.

Funding: This study was financially supported by the Forest Research and Development Centre, the Ministry of Environment and Forestry of Indonesia. The publication cost of this study was covered by World Agroforestry (ICRAF) Indonesia.

Institutional Review Board Statement: Not applicable.

Informed Consent Statement: Not applicable.

Acknowledgments: The authors thank the Forest Research and Development Centre and World Agroforestry (ICRAF) Indonesia for providing funding for this research and publication. The authors also thank UPTD of WAR GFP for facilitation during the study. Special thanks to Sumarhani for her assistance in field data collection and Lutfy Abdulah for his assistance in data analysis. Our appreciation and thanks go to related stakeholders for their support and participation in providing necessary data and information and to agroforestry farmers at Cilimus and Bogorejo Villages for their cooperation during field observation and series of interviews. We thank anonymous reviewers for their detail comments and corrections.

Conflicts of Interest: This research has followed the guidelines for Ethical Clearance of Research and Scientific Publications issued by the Indonesian Institute of Science No.08/E/2013. The authors declare no conflict of interest. 


\section{Appendix A}

Table A1. Cultivated species in the plots of interviewed farmers in Bogorejo and Cilimus Villages in WAR GFP.

\begin{tabular}{|c|c|c|c|}
\hline Classification & Scientific Name & Common Name & Family \\
\hline \multirow{27}{*}{$\begin{array}{l}\text { Multipurpose tree } \\
\text { species (MPTS) }\end{array}$} & Aleurites moluccana & Candlenut & Euphorbiaceae \\
\hline & Annona muricata & Soursop & Annonaceae \\
\hline & $\begin{array}{l}\text { Archidendron } \\
\text { pauciflorum }\end{array}$ & Jengkol & Fabaceae \\
\hline & Areca catechu & Areca nut & Arecaceae \\
\hline & Arenga pinnata & Sugar Palm & Arecaceae \\
\hline & Artocarpus altilis & Breadfruit & Moraceae \\
\hline & Artocarpus heterophylla & Jackfruit & Moraceae \\
\hline & Ceiba pentandra & Kapok tree & Malvaceae \\
\hline & Citrus sp. & Orange & Rutaceae \\
\hline & Cocos nucifera & Coconut & Arecaceae \\
\hline & Coffea arabica & Coffee & Rubiaceae \\
\hline & Cytrus hystrix & Lime & Rutaceae \\
\hline & Durio zibethinus & Durian & Malvaceae \\
\hline & Garcinia xanthochymus & Asam kandis & Clusiaceae \\
\hline & Gnetum gnemon & Melinjo & Gnetaceae \\
\hline & Hevea brasiliensis & Rubber & Euphorbiaceae \\
\hline & Lansium domesticum & Duku & Meliaceae \\
\hline & Mangifera indica & Mango & Anacardiaceae \\
\hline & Moringa oleifera & Moringa & Moringaceae \\
\hline & Musa sp. & Banana & Musaceae \\
\hline & Myristica fragrans & Nutmeg & Myristicaceae \\
\hline & Nephelium lappaceum & Rambutan & Sapindaceae \\
\hline & Parkia spesiosa & Petai & Fabaceae \\
\hline & Persea americana & Avocado & Lauraceae \\
\hline & Psidium guajava & Guava & Myrtaceae \\
\hline & Syzygium aromaticum & Clove & Myrtaceae \\
\hline & Theobroma cacao & Cacao & Malvaceae \\
\hline \multirow{22}{*}{ Forest species } & Albizzia procera & Ki hiyang/weru & Fabaceae \\
\hline & Alstonia scholaris & Pulai & Apocynaceae \\
\hline & Antidesma bunins & Kayu wuwingan & Euphorbiaceae \\
\hline & Antocephalus cadamba & Kayu kelompayan & Rubiaceae \\
\hline & $\begin{array}{l}\text { Anocephalus } \\
\text { macrophyllus }\end{array}$ & Jabon merah & Rubiaceae \\
\hline & Bischofia javanica & Kayu gintung & Euphorbiaceae \\
\hline & Dalbergia latifolia & Sonokeling & Fabaceae \\
\hline & $\begin{array}{l}\text { Dracontomelon } \\
\text { mangiferum }\end{array}$ & Kayu dahu/gahu & Anacardiaceae \\
\hline & Erythrina variegata & Dadap & Fabaceae \\
\hline & Ficus variegata & Kayu kondang & Moraceae \\
\hline & Gigantochloa spp. & Bamboo & Poaceae \\
\hline & Litsea spp. & Medang & Lauraceae \\
\hline & Michelia champaca & Cempaka & Magnoliaceae \\
\hline & Pangium edule & Kayu kepayang & Achariaceae \\
\hline & Pterocarpus indicus & Kayu kembang & Fabaceae \\
\hline & Pterospermum spp. & Bayur & Sterculiaceae \\
\hline & Swietenia macrophylla & Mahogany & Meliaceae \\
\hline & Tetrameles nudiflora & Kayu binong tabu & Datiscaceae \\
\hline & Alpinia galangal & Galangal & Zingiberaceae \\
\hline & Capsicum sp. & Chili & Solanaceae \\
\hline & Colocasia esculenta & Taro & Araceae \\
\hline & Curcuma longa & Tumeric & Zingiberaceae \\
\hline
\end{tabular}


Table A1. Cont.

\begin{tabular}{cccc}
\hline Classification & Scientific Name & Common Name & Family \\
\hline Understory & Cymbopogon citratus & Lemongrass & Poaceae \\
species & Elettaria cardamomum & Cardamom & Zingiberaceae \\
& Piper nigrum & Pepper & Piperaceae \\
& Piper retrofractum & Java chili & Piperaceae \\
Vanilla planifolia & Vanila & Orchidaceae \\
& Zingiber officinale & Ginger & Zingiberaceae \\
\hline
\end{tabular}

Table A2. Correlation between variables of agroforestry characteristics according to Pearson correlation coefficient.

\begin{tabular}{cccccc}
\hline Variables & $\begin{array}{c}\text { Distance from } \\
\text { Farmer's Settlement } \\
\text { to Farming }\end{array}$ & $\begin{array}{c}\text { Size of } \\
\text { Cultivated Area }\end{array}$ & $\begin{array}{c}\text { Number of } \\
\text { Harvested Species }\end{array}$ & $\begin{array}{c}\text { Number of Non- } \\
\text { harvested Species }\end{array}$ & $\begin{array}{c}\text { Farmer's Activity } \\
\text { Distance }\end{array}$ \\
Area & 1 & 0.1609 & -0.0408 & 0.1390 & -0.1913 \\
Harvested & -0.1609 & 1 & $\mathbf{0 . 4 1 6 0}$ & $\mathbf{0 . 3 3 4 3}$ & -0.2041 \\
Non-harvested & 0.1390 & $\mathbf{0 . 4 1 6 0}$ & 1 & 0.0793 & 0.0087 \\
Activity & -0.1913 & $\mathbf{0 . 3 3 4 3}$ & 0.0793 & 1 & -0.1200 \\
\hline
\end{tabular}

Note: Values in bold are different from 0 with a significance level alpha $=0.05$.

\section{References}

1. Pimentel, D.; Stachow, U.; Takacs, D.A.; Brubaker, H.W.; Dumas, A.R.; Meaney, J.J.; O’Neil, J.A.S.; Onsi, D.E.; Corzilius, D.B. Observing biological diversity in agricultural/forestry. Bioscience 1992, 42, 354-362. [CrossRef]

2. Gray, C.L.; Hill, S.L.L.; Newbold, T.; Hudson, L.N.; Börger, L.; Contu, S.; Hoskins, A.J.; Ferrier, S.; Purvis, A.; Scharlemann, J.P.W. Local biodiversity is higher inside than outside terrestrial protected areas worldwide. Nat. Commun. 2016, 7, 12306. [CrossRef] [PubMed]

3. WRI; IUCN; UNEP. Global Biodiversity Strategy; WRI: Washington, DC, USA; IUCN: Gland, Switzerland; UNEP: Nairobi, Kenya, 1992; p. 224.

4. Butchart, S.H.; Clarke, M.; Smith, R.J.; Sykes, R.E.; Scharlemann, J.P.; Harfoot, M.; Buchanan, G.M.; Angulo, A.; Balmford, A.; Bertzky, B.; et al. Shortfalls and solutions for meeting national and global conservation area targets. Conserv. Lett. 2015, 8, 329-337. [CrossRef]

5. Larsen, F.W.; Turner, W.R.; Mittermeier, R.A. Will protection of $17 \%$ of land by 2020 be enough to safeguard biodiversity and critical ecosystem services? Oryx 2015, 49, 74-79. [CrossRef]

6. UPTD Tahura WAR. Blok Pengelolaan Taman Hutan Raya Wan Abdul Rachman, Provinsi Lampung; UPTD Tahura Wan Abdul Rachman: Bandar Lampung, Indonesia, 2017; p. 50.

7. Handoko; Darmawan, A. Perubahan tutupan hutan di Taman Hutan Raya Wan Abdul Rachman. J. Sylva Lestari 2015, 3, 43-52. [CrossRef]

8. Simarmata, G.B.; Qurniati, R.; Kaskoyo, H. Faktor-faktor yang mempengaruhi pemanfaatan lahan Taman Hutan Raya Wan Abdul Rachman. J. Sylva Lestari 2018, 6, 60-67. [CrossRef]

9. Wulandari, C.; Budiono, P.; Yuwono, S.B.; Herwanti, S. Adoption of agroforestry patterns and crop systems around register 19 forest park, Lampung province, Indonesia. J. Manaj. Hutan Trop. 2014, 20, 86-93. [CrossRef]

10. Minarningsih; Murniati. Complex agroforestry system in Wan Abdul Rachman Grand Forest Park: Composition and characteristics of food-producing plants. In Proceedings of the International Conference on Forest Conservation and Management (ICFCM) 2019: Innovative Solution for Managing Tropical Forests and Conserving Biodiversity to Support Sustainable Development Goals, Bogor, Indonesia, 28 August 2019; IOP Conference Series: Earth and Environmental Science. IOP Publishing Ltd.: Bristol, UK, 2020; Volume 533, p. 012018. [CrossRef]

11. Froufe, L.C.M.; Schwiderke, D.K.; Castilhano, A.C.; Cezar, R.M.; Steenbock, W.; Seoane, E.; Bognola, I.A.; Vezzani, F.M. Nutrient cycling from leaf litter in multi strata successional agroforestry systems and natural regeneration at Brazilian Atlantic Rainforest Biome. Agrofor. Syst. 2020, 94, 159-171. [CrossRef]

12. Nurlia, A.; Martin, E.; Winarno, B. Pengelolaan kolaboratif kawasan hutan di Tahura WAR. In Proceedings of the Seminar Teknologi Perbenihan, Silvikultur dan Kelembagaan dalam Peningkatan Produktivitas Hutan dan Lahan, Bandarlampung, Indonesia, 11 August 2015; Mindawati, N., Bramasto, Y., Astho, A., Rahmat, M., Sudrajat, D.J., Eds.; Pusat Penelitian dan Pengembangan Hutan: Bogor, Indonesia, 2015; pp. 229-235.

13. Nair, P.K.R.; Kumar, B.M.; Nair, V.D. Agroforestry as a strategy for carbon sequestration. J. Plant Nutr. Soil Sci. 2009, 172, 10-23. [CrossRef] 
14. Catacutan, D.C.; Finlayson, R.F.; Gassner, A.; Perdana, A.; Lusiana, B.; Leimona, B.; Simelton, E.; Öborn, I.; Gamma, G.; Roshetko, J.M.; et al. ASEAN Guidelines for Agroforestry Development; The ASEAN Secretariat: Jakarta, Indonesia, 2018 ; p. 48.

15. Jumiyati, S.; Arsyad, M.; Rajindra; Pulubuhu, D.A.T.; Hadid, A. Cocoa Based Agroforestry: An Economic Perspective in Resource Scarcity Conflict Era. In Proceedings of the International Conference on Food Security and Sustainable Agriculture in the Tropics, Sulawesi Selatan, Indonesia, 24-25 October 2017; IOP Conference Series: Earth and Environmental Science. IOP Publishing Ltd.: Bristol, UK, 2018; Volume 157, p. 012009. [CrossRef]

16. Knowler, D.; Bradshaw, B. Farmers' adoption of conservation agriculture: A review and synthesis of recent research. Food Policy 2007, 32, 25-48. [CrossRef]

17. Basamba, T.A.; Mayanja, C.; Kiiza, B.; Nakileza, B.; Matsiko, F.; Nyende, P.; Bacwayo, K.E.; Tumushabe, A.; Ssekabira, K. Enhancing adoption of agroforestry in the eastern agro-ecological zone of Uganda. Int. J. Ecol. Sci. Environ. Eng. 2016, 3, $20-31$.

18. McNally, A.; Arsenault, K.; Kumar, S.; Shukla, S.; Peterson, P.; Wang, S.; Funk, C.; Peters-Lidard, C.D.; Verdin, J.P. A land data assimilation system for sub-Saharan Africa food and water security applications. Sci. Data 2017, 4, 170012. [CrossRef]

19. Gebru, B.M.; Wang, S.W.; Kim, S.J.; Lee, W.K. Socio-ecological niche and factors affecting agroforestry practice adoption in different agroecologies of southern Tigray, Ethiopia. Sustainability 2019, 11, 3729. [CrossRef]

20. Oostendorp, R.H.; Zaal, F. Land acquisition and the adoption of soil and water conservation techniques: A Duration Analysis for Kenya and The Philippines. World Dev. 2012, 40, 1240-1254. [CrossRef]

21. Jara-Rojas, R.; Russy, S.; Roco, L.; Fleming-Muñoz, D.; Engler, A. Factors affecting the adoption of agroforestry practices: Insights from silvopastoral systems of Colombia. Forests 2020, 11, 648. [CrossRef]

22. Nkamleu, G.B.; Manyong, V.M. Factors affecting the adoption of agroforestry practices by farmers in Cameroon. Small-Scale For Econ. Manag. Policy 2005, 4, 135-148. [CrossRef]

23. Jera, R.; Ajayi, O.C. Logistic modelling of smallholder livestock farmers' adoption of tree-based fodder technology in Zimbabwe. Agrekon 2008, 47, 379-392. [CrossRef]

24. Cedamon, E.; Nuberg, I.; Pandit, B.H.; Shrestha, K.K. Adaptation factors and futures of agroforestry systems in Nepal. Agrofor Syst. 2018, 92, 1437-1453. [CrossRef]

25. Sabastian, G.E.; Yumn, A.; Roshetko, J.M.; Manalu, P.; Martini, E.; Perdana, A. Adoption of silvicultural practices in smallholder timber and NTFPs production systems in Indonesia. Agrofor. Syst. 2019, 93, 607-620. [CrossRef]

26. Ranjit, Y. Economic impact of people's participation in forest management (A case study of Kabhre Palanchwok, Nepal). Econ. J. Dev. Issues 2011, 13, 139-151. [CrossRef]

27. Iftekhar, M.S.; Hoque, A.K.F. Causes of forest encroachment: An analysis of Bangladesh. GeoJournal 2005, 62, 95-106. [CrossRef]

28. Koech, C.P. Household factors affecting the implementation of forest conservation strategies: A case of south Nandi forest, Nandi county, Kenya. Open J. Soc. Sci. 2020, 8, 125-144. Available online: https://www.scirp.org/journal/jss (accessed on 6 November 2021). [CrossRef]

29. Sugiyono. Metode Penelitian Kuantitatif Kualitatif Dan RED; Alfabeta: Bandung, Indonesia, 2010; pp. 81-86.

30. Torres-Salinas, D.; Robinson-Garcia, N.; Jiménez-Contreras, E.; Herrera, F.; Delgado-López-Cózar, E. On the use of biplot analysis for multivariate bibliometric and scientific indicators. J. Am. Soc. Inf. Sci. Technol. 2013, 64, 1468-1479. [CrossRef]

31. Diansari, D.; Sriati, S.; Lionardo, A. Implementasi peraturan daerah provinsi Lampung No. 3 Tahun 2012 tentang kolaborasi pengelolaan Taman Hutan Raya Wan Abdul Rachman. Demogr. J. Sriwij. 2015, 2, 40-50. Available online: http:/ / ejournal-pps. unsri.ac.id/index.php/dejos/article/view/44 (accessed on 6 November 2021).

32. Suharti, S.; Darusman, D.; Nugroho, B.; Sundawati, L. Economic valuation as a basis for sustainable mangrove resource management: A case in east Sinjai, south Sulawesi. J. Manaj. Hutan Trop. 2016, 22, 13-23. [CrossRef]

33. Hanif, M.A.; Roy, R.M.; Bari, M.S.; Ray, P.C.; Rahman, M.S.; Hasan, M.F. Livelihood improvements through agroforestry: Evidence from northern Bangladesh. Small-Scale For. 2018, 17, 505-522. [CrossRef]

34. Measham, T.G.; Lumbasi, J. Success factors for community based natural resource management (CBNRM): Lessons from Kenya and Australia. Environ. Manag. 2013, 52, 649-659. [CrossRef]

35. Ndalama, E.; Kamanga-Thole, G.; Missanjo, E. Agroforestry contribution to the improvement of rural community livelihoods in Balaka, Malawi. Int. J. For. Hortic. 2015, 1, 5-11.

36. Braga, D.P.P.; Domene, F.; Gandara, F.B. Shade trees composition and diversity in cacao agroforestry systems of southern Para, Brazilian Amazon. Agrofor. Syst. 2018, 93, 1409-1421. [CrossRef]

37. Cannell, M.G.R. Plant management in agroforestry: Manipulation of trees, population densities and mixtures of trees and herbaceous crops. In Plant Research and Agroforestry; Huxley, P.A., Ed.; ICRAF: Nairobi, Kenya, 1983; pp. 455-502.

38. Suprayogo, D.; Van Noordwijk, M.; Hairiah, K.; Cadisch, G. The inherent 'safety-net' of an acrisol: Measuring and modelling retarded leaching of mineral nitrogen. Eur. J. Soil Sci. 2002, 53, 185-194. [CrossRef]

39. Yulianti, T.; Abdoellah, S.; Suprayogo, D.; Sari, N.P. Cocoa production as affected by shade tree species and soil quality. Pelita Perkeb. 2018, 34, 80-89. [CrossRef]

40. Tetteh, D.A.; Asase, A.; Ofori-Frimpong, K.; Attuquayefio, D. Effect of cocoa farming intensification on biodiversity and ecosystem properties in southern Ghana. J. Ecol. Nat. Environ. 2018, 10, 172-181. [CrossRef]

41. Amare, D.; Wondie, M.; Mekuria, W.; Darr, D. Agroforestry of smallholder farmers in Ethiopia: Practices and benefits. Small-Scale For. 2018, 18, 39-56. [CrossRef] 
42. Pumariño, L.; Sileshi, G.W.; Gripenberg, S.; Kaartinen, R.; Barrios, E.; Muchane, M.N.; Midega, C.; Jonsson, M. Effects of agroforestry on pest, disease and weed control: A meta-analysis. Basic Appl. Ecol. 2015, 16, 73-82. [CrossRef]

43. Swallow, B.; Boffa, J.M.; Sara, S. The potential for agroforestry to contribute to the conservation and enhancement of landscape biodiversity. In World Agroforestry into the Future; Garrity, D., Okono, A., Grayson, M., Parrot, S., Eds.; World Agroforestry Centre: Nairobi, Kenya, 2006; pp. 95-101.

44. Mbene, F.; Weber, J.; Tougiani, A.; Moussa, B.; Mahamane, L.; Bationo, B.; Diallo, B.; Sigue, H.; Dakouo, J.M.; Samaké, O.; et al. Farmers' preferences for tree functions and species in the west African Sahel. For. Trees Livelihoods 2011, 20, 113-136. [CrossRef]

45. Dimobe, K.; Tondoh, J.E.; Weber, J.C.; Bayala, J.; Ouédraogo, K.; Greenough, K. Farmers'preferred tree species and their potential carbon stocks in southern Burkina Faso: Implications for biocarbon initiatives. PLoS ONE 2018, 13, e0199488. [CrossRef] [PubMed]

46. Wartenberg, A.C.; Blaser, W.J.; Janudianto, K.N.; Roshetko, J.M.; Van Noordwijk, M.; Six, J. Farmer perceptions of plant-soil interactions can affect adoption of sustainable management practices in cocoa agroforests: A case study from southeast Sulawesi. Ecol. Soc. 2018, 23, 18. [CrossRef]

47. Wulandari, C.; Bintoro, A.; Rusita, R.; Santoso, T.; Duryat; Kaskoyo, H.; Erwin; Budiono, P. Community forestry adoption based on multipurpose tree species diversity towards to sustainable forest management in ICEF of University of Lampung, Indonesia. Biodiversitas 2018, 19, 1102-1109. [CrossRef]

48. Dhakal, A.; Rai, R.K. Who adopts agroforestry in a subsistence economy?-Lessons from the Terai of Nepal. Forests 2020, 11, 565. [CrossRef]

49. Jose, S. Agroforestry for ecosystem services and environmental benefits: An overview. Agrofor. Syst. 2009, 76, 1-10. [CrossRef]

50. Ong, C.; Black, C.R.; Wilson, J.; Muthuri, C.; Bayala, J.; Jackson, N.A. Agroforestry: Hydrological impacts. In Reference Module in Food Science; Elsevier: Amsterdam, The Netherlands, 2017. [CrossRef]

51. Dollinger, J.; Jose, S. Agroforestry for soil health. Agrofor. Syst. 2018, 92, 213-219. [CrossRef]

52. Fifanou, V.G.; Ousmane, C.; Gauthier, B.; Brice, S. Traditional agroforestry systems and biodiversity conservation in Benin (West Africa). Agrofor. Syst. 2011, 82, 1-13. [CrossRef]

53. Syofiandi, R.R.; Hilmanto, R.; Herwanti, S. Analisis pendapatan dan kesejahteraan petani agroforestri di kelurahan Sumber Agung kecamatan Kemiling kota Bandar Lampung. J. Sylva Lestari 2016, 4, 7-26. [CrossRef]

54. Jose, S. Agroforestry for conserving and enhancing biodiversity. Agrofor. Syst. 2012, 85, 1-8. [CrossRef]

55. Gockowski, J.; Asten, P.V. Agricultural intensification as a climate change and food security strategy for sub-Saharan Africa. In Climate Change Mitigation and Agriculture; Wollenberg, E., Nihart, A., Tapio-Bostro, M.L., Grieg-Gran, M., Eds.; Routledge: London, UK; New York, NY, USA, 2012; pp. 382-390.

56. Mbow, C.; Van Noordwijk, M.; Luedeling, E.; Neufeldt, H.; Minang, P.A.; Kowero, G. Agroforestry solutions to address food security and climate change challenges in Africa. Curr. Opin. Environ. Sustain. 2014, 6, 61-67. [CrossRef]

57. Koohafkan, P.; Altieri, A.M.; Gimenez, H.E. Green agriculture: Foundations for biodiverse, resilient and productive agricultural systems. Int. J. Agric. Sustain. 2012, 10, 61-75. [CrossRef]

58. Place, F.; Ajayi, O.C.; Torquebiau, E.; Detlefsen, G.; Gauthier, M.; Buttoud, G. Improved policies for facilitating the adoption of agroforestry. In Agroforestry for Biodiversity and Ecosystem Services—Science and Practice; Kaonga, M., Ed.; InTech: London, UK, 2012; pp. 113-128. [CrossRef]

59. Widjayanto, N. Agroforestri: Masa Depan Pemanfaatan Lahan Hutan Produksi. Available online: https://www.forestdigest. com/detail/28/agroforestri-masa-depan-pemanfaatan-lahan-hutan-produksi (accessed on 6 November 2021).

60. Saha, R.; Ghosh, P.K.; Mishra, V.K.; Majumdar, B.; Tomar, J. Can agroforestry be a resource conservation tool to maintain soil health in the fragile ecosystem of north-east India? Outlook Agric. 2010, 39, 191-196. [CrossRef]

61. Murthy, I.K.; Gupta, M.; Tomar, S.; Munsi, M.; Tiwari, R.; Hedge, G.T.; Ravindranath, N.H. Carbon sequestration potential of agroforestry systems in India. J. Earth Sci. Clim. Chang. 2013, 131, 1-7. [CrossRef]

62. Kholifah, U.N.; Wulandari, C.; Santoso, T.; Kaskoyo, H. Kontribusi agroforestri terhadap pendapatan petani di kelurahan Sumber Agung kecamatan Kemiling kota Bandar Lampung. J. Sylva Lestari 2017, 5, 39-47. [CrossRef]

63. Kiyani, P.; Andoh, J.; Lee, Y.; Lee, D.K. Benefits and challenges of agroforestry adoption: A case of Musebeya sector, Nyamagabe District in the southern province of Rwanda. For. Sci. Technol. 2017, 13, 174-180. [CrossRef]

64. Chakraborty, M.; Haider, M.Z.; Rahaman, M.M. Socio-economic impact of cropland agroforestry: Evidence from Jessore district of Bangladesh. Int. J. Res. Agric. For. 2015, 2, 11-20. Available online: http:/ /ijraf.org/pdf/v2-i1/3.pdf (accessed on 6 November 2021).

65. Rahman, S. Agroforestry: Why Don't Farmers Plant More Trees? Smallholder Tree Farming in Fragmented Tropical Landscapes Can Boost Crop Production and Protect the Landscape Too. Available online: https:/ / forestsnews.cifor.org/55549/agroforestrywhy-dont-farmers-plant-more-trees?fnl=en (accessed on 6 November 2021). 